\title{
Impact of Integrated Marketing Communication on Consumers Purchase Decisions
}

\author{
Ulita Umbreen ${ }^{1}$ \\ Dr. Tahir Ali 2
}

\begin{abstract}
The integrated marketing communication (IMC) is one of the important communication trend adopted by advertising and business organizations during last decade. This research is conducted to find out the impact of IMC practices on consumers' purchase decisions in Pakistan. In this age of globalization, with the spread of advanced and updated technologies and increase in well-informed customers, it has become essential for the business market to be more efficient to make powerful impact on the target audience and market. In Pakistan, the business market has started progressing towards an integrated approach to achieving efficiency by synergy and this concept has become one of the most significant examples of development in the marketing discipline. This research highlights the importance of IMC activities with respect to influencing consumers' purchase decisions. Through consumers feedback the research successfully found consumers preferences for IMC tools, activities, demographic profiles and buying behavior. The descriptive research design is adopted and interviews and questionnaires are used for data collection. Finally, the research concludes that consumers are becoming demanding as their demographic profiles and buying behavior are influenced by IMC activities which contribute in consumers' final purchase decisions.
\end{abstract}

Keywords: Integrated marketing communications, consumer behavior, consumers purchase decisions, marketing communication tools and advanced technology, marketing mix

\section{Introduction}

One of the most substantial trends adopted by the organizations is integrated marketing communications (IMC) with respect to its products and services marketing activities. Currently, the global environment is rapidly changing. For instance, exchange of knowledge, technology and communication play a vital role for domestic business to further move with expansion into global market, as avoid the concern of physical patrolling (Reid \& Mavondo, 2005). Today, firms are compelled by rapidly increasing competition, social concerns and environment uncertainties (Knox \& Maklan, 2004) and it is necessity for the survival of firms to fulfill the expectations and demands of influential stakeholders (Logsdon \& Wood, 2002).

\subsection{Background of the Study}

Advanced technology and communication development has galvanized the emanation of information technology development has encouraged the emergence of modern and advance communication channels that have aggrandized the alternative accessible to organizations for contriving the relationships with the stakeholders (Albesa, 2007).This study highlights the IMC practices of the companies and its impact on the consumers' purchasing decision which provide the insight about basic understanding of IMC by the Pakistani organizations. So consumers would be able to understand and evaluate the future of IMC practices in

${ }^{1}$ Ulita Umbreen is visiting faculty at Indus University, Karachi, uulita@yahoo.com ${ }^{2}$ Dr. Tahir Ali is Professor, Department of Commerce, University of Karachi, ali2122@ymail.com

\begin{tabular}{llll|l}
\hline JISR-MSSE & Volume 11 & Number 1 & Jaunary - June 2013 & 25
\end{tabular}


Pakistan. In the same context, the relevant literature explains that IMC is not a new approach. It has already been practiced by several companies as their departments are involved in major communications and together they are performing marketing activities for profits, stability and competitions (Waheeduzzaman \& Dube, 2004; Duncan and Everett,1993). The study aims to explore the necessity of IMC practices in the context of Pakistani market. Finally, it explores brand's IMC implementations and the extent to which IMC activities are correlated with consumer purchase decision.

\subsection{Research Problem}

This research aims to study the impact of incorporating the integrated marketing communications on consumers purchase decisions. Also, it finds the key relationship between variables: advertising, technology, sales promotions, direct marketing, public relation and consumers purchase decisions.

\subsection{Significance and Scope}

This research would help the organizations in understanding the consumers' preferences with respect to their implementations and practices of IMC activities. It would enable them to effectively utilize the tools of marketing mix incorporating the IMC activities and to cater to their target audience effectively.

\section{Literature Review}

\subsection{Integrated Marketing Communications (IMC)}

This section defines the integrated marketing communications, marketing communications in contrast to the old practices of marketing communications, evolution of IMC and its transformation by marketers and marketing agencies. Due to changing trends in international market, companies have started practicing the integrated marketing communication instead of traditional marketing mix. Schultz (1998) introduced "business process" to define IMC which most appropriately describes the nature and the attributes of integration as IMC is not only associated with the integration activity of several functional areas of communication and marketing but also involves organization's other functional areas which are consumerdriven. Furthermore, the concept of "business process" braces the observations of researchers Fill (2002) and Jones et al (2004) that the approach IMC has become from being considered exclusively as a process of communication, to the degree of a management process. Moreover, marketing communication able to efficiently support the company in drawing out the favorable consumers feedback (Duncan \& Moriarty, 1998). The IMC strategically started appreciable when organizations considered IMC as a set of implementations which involve development, planning, effective execution, and evaluation of measurable, strongly coordinated, effective brand communications programs interacting over time with stakeholders, potential consumers, prospects and other associates, appropriate internal and external audiences (Schultz, 2004). Therefore, effective IMC is a component of an effective strategy of brand equity. Moreover, effectively focused IMC explore and enhance the brand efficacy of the company's portfolio which effectively influences brand and brand equity. 
According to research of Low (2000), Levinson (2001) and Zahay et al. (2004) the firms which implements IMC are customer-centered, making consistent relationship with the target audiences and market, procedures, models and systems for associating the business and management functional areas of the organization. The contiguous communication between consumers and organization affirmed to support the implementation of IMC by catering information about consumers and getting the feedback. Adverse market ambiance characterized by close competition and a deficiency of exploitive opportunities, dynamic and strategic environments described by rapid advance technologies and expeditiously changing needs and preferences of consumers are acknowledged to have a compelling impacts on business outcomes and performance (Rust et al. 2004). The aspiration to get the competitive edge in such circumstantial estate may administer impulsion for organizations to execute the IMC practices to facilitate the effective strategic activities.

Direct marketing is defined as personal interaction or communication between the customer and marketer. As Kallmeyer and Abratt (2001) explained that personal communication contemplated as more efficient as it provides prompt feedback informing the communicator about the delivery of message conveyed or nit conveyed appropriately. The main purpose of direct marketing is to get the immediate feedback of the customer. Direct marketing tactics includes door to door selling where sales persons improve and augment customer loyalty and retention, direct mail and telemarketing. As Curtis (1999) asserted that due to the revolution of high technology communication the least preferred door to door selling has revived its importance through advance high technological communication tools which includes telephone, emails and data base. Data base permit the firms to amend the preferred target audiences, then segment them effectively and communicate with them directly. Emphasizing the importance of direct marketing Krishnan (2001) stated that manufacturers' use their retailer network as an effective direct marketing tool. According to the researcher Geller (1998) direct mail being the most important strategy used to recognize the customers about their importance and compatibility.

Direct marketing permits the marketers to communicate with the customers personally but due to limited resources and time direct marketing needs an integration and coordination with other indirect marketing tools like sales promotion which supports consumers in brand identification, recognitions and retention. Sales promotion is more result and action determined which is executed to encourage consumers to purchase products. As Fill (2002) termed sales promotion as "short term inducements to consumers purchasing activity".

Firms use diverse techniques to bring their mission of selling and purchasing. Different sales promotion techniques have been adopted by firms to cater to the large audience. These techniques include discounts, coupons, price reduction, premium contests and other techniques like trade promotion which consists of packaging, labeling and point of purchase display. Implementation of sales promotion techniques requires short time period to full fill short and specific objectives. Sales promotion is the most effective communication tool and praises other mass communication strategy, including personal selling and advertising but it is not unlimited in its practices and failed to be the substitute of personal selling and advertising (Eagle \& Kitchen, 2000). Hence, these kinds of limitations made sales promotion practices and techniques more coordinated and integrated with other strategies consisting of public relations and advertising. 
Advertising is an activity which builds a brand identity, brand recognition and promotes products making firm's reputation in the market. Tellis (2006) argued that advertising administers details of organization, product/ services, brand identity and supports in identifying the role and performance of products/ services for each targeted consumer. Integration tactics have been added by practitioners as now advertising campaigns has been designed to provide knowledge about the need then information of the product rather than enforcing or motivating the consumer to make prompt buying decisions. One of the rapidly flourishing extrinsic factor is advanced technological aspects in the globalized market (Berthon \& Campbell, 2008). The impact of technology advancement changes the culture and implications of the management, hence the dynamic field of IMC is the development of communications through advance and interactive technology known as media, specifically the Internet. Online plat forms enforced marketers to emphasize on specified and targeted market (Steinbock, 2000). Marketers practicing cohesive, coordinated and effective integrated program that effectively communicate and persuade consumers.

The personification of Public Relations had been noted and proposed by several scholars, as the part of IMC process. The public relations play an important role which has significant aspects. According to Baker and Mitchell (2000), the traditional practices of attaining the consumers respect and understanding, while being important, it has been complemented by countless marketing familiarized approach. As Belch (2004) asserted that several organizations are more towards sponsoring events so focusing mass target market consists of national and international markets. Duncan (2000) developed the IMC process model and defined that IMC contemplate all sources of the company's association which a customer has with the brand's offering as promising delivery channels for the forthcoming messages. Based on this

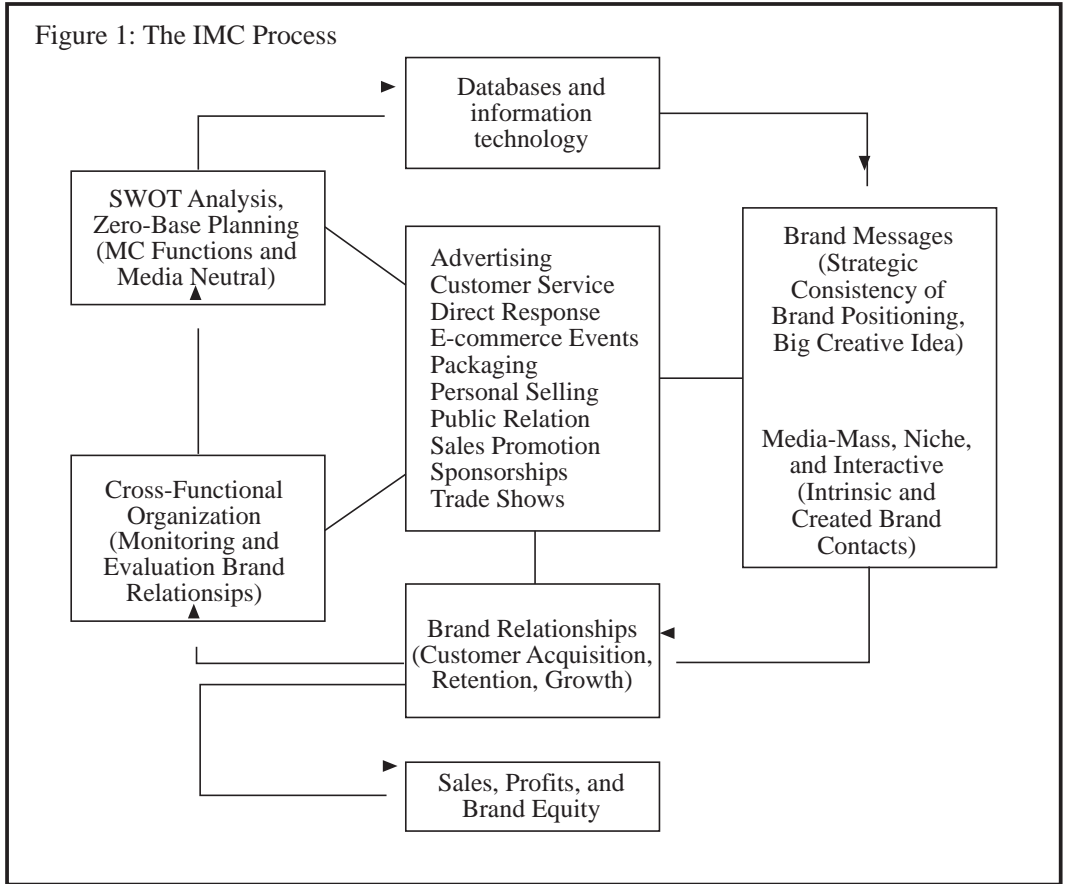

Source: The IMC Process Model (Duncan, 2002) 
context the research variables have been developed. The figure affirms an ongoing, orbicular process that develops brand value in the mode of brand equity, sales and profits, where there is no beginning and ending-oriented retaining, obtaining and growing custom. The abovementioned figure elaborates that IMC is a continuous process to efficiently communicate the brand's offering to the target audience in a way getting the desirable results.

\section{Research Methodology}

\subsection{Research Design}

This is a qualitative descriptive research and contains interviews and survey questionnaires. Qualitative descriptive design is well-considered fusion of population, sampling and data collection which are based on re-presentational and analysis (Devers \& Frankel, 2000). Another researcher Creswell (2003) explained that the qualitative descriptive study is specifically amenable for achieving the direct feedback from the target audience in a particular environment and seeks the descriptive validity. Interview questionnaires were filled by brand managers of FMCG firms and survey questionnaires were filled by consumers living in Karachi. The 3 identified firms were P\&G, Unilever and Engro Foods Ltd. To collect the appropriate data for studying the impact of "IMC on consumer purchase decisions", the nonprobability judgmental sampling for the interviews and questionnaire survey from the brand managers of FMCG firm were included. The sample size consisted of an interview from brand manager of Safeguard from P\&G. The questionnaires were filled by brand managers and assistant brand managers of $P \& G$, Unilever and Engro Foods firms. The non-probability convenience sampling for the questionnaire survey was consisted of 500 consumers limited to Karachi, because for the researcher it was convenient to select the respondents which were easily approachable and agreed to fill the survey questionnaire reducing cost and saving time. To fulfill the appropriate criteria the questionnaires were distributed in universities, saloons, shopping centers, and malls located in Gulshan, Clifton and North Nazimabad of Karachi.

\subsection{Research Variables}

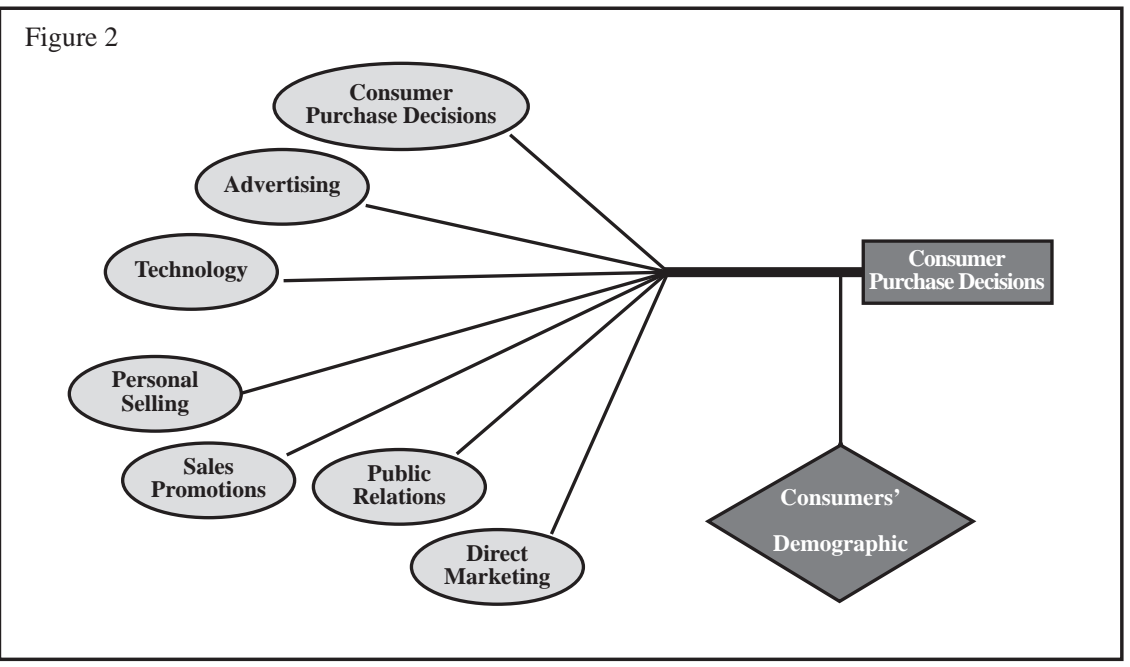




\section{Data Analysis}

Total estimated population of Karachi is over 21 million and the population of middle class and above is approximately 17 million so population included in this study is SEC A and BAC Nielsen. This study has used both qualitative and quantitative method. The empirical findings taken from interviews of brand managers were analyzed by following the process, including transcribed data, organization, coding, then personal reflections were noted. After that similarity of constructs, patterns, differences and common sequences among sub groups and themes were identified, generalized and formalized through sorting and sifting (Devers \& Frankel, 2000). SPSS and Microsoft office were used to accomplish the analysis. The complete returned questionnaires' data after coding was transformed into the 17.0 version SPSS data file. Descriptive and Frequency analyses were done and data was analyzed. Hypotheses were developed and examined by running correlations. To find the reliability, the scale test of Cronbach alpha coefficient was applied to compute the consistency of the variables and constructs (Weitzman, 1999). The tested items found near to .76 which is an acceptable value to retain for this research. The respondents' feedback on questionnaires were analyzed against the research objectives. The consumers' perspective is illustrated in this section. In the research method the researcher summarized the consumer survey procedure, now the empirical data collected and its findings are represented. Overall, 367 respondents filled the questionnaires completely which were acceptable out of 550 questionnaires.

\subsection{Demographic Analysis}

The demographics of the respondents are illustrated in the demographic matrix of consumers. The data for this research was collected from Karachi; consumers with general understanding of brands and marketing were the targeted audience who were accessible in the universities, saloons, malls and others through online platforms. Total 367 questionnaires were completely filled which were consisted of 126 men and 241 women. The data showed that $44 \%$ consumers were between the age of $30-45$ years, $30 \%$ were between $18-30,15 \%$ consumers were less than 18 years and $11 \%$ belonged to 45 +years of age. Their income level showed that most of them approximately $42 \%$ showed their income level between Rs.71, 000- 99,000, $24 \%$ consumers mentioned their income between Rs. 100,000-150,000, 20\% consumers mentioned between Rs. 51,000-70,000 and 14\% were belonged to less than Rs.50,000. The data analysis showed that $51 \%$ consumers were graduates, $21 \%$ were Master's degree holders, $15 \%$ were intermediate or did their A-levels and $13 \%$ did their secondary schooling.

Table 1: Consumers' Demographic Matrix

\begin{tabular}{|c|c|c|c|c|c|c|c|}
\hline S.No & $\begin{array}{l}\text { Demographic } \\
\text { Detatils }\end{array}$ & Frequency & Percentage & S.No & $\begin{array}{l}\text { Demographic } \\
\text { Detatils }\end{array}$ & Frequency & Percentage \\
\hline 1. & GENDER & & & 3. & \multicolumn{3}{|l|}{ INCOME } \\
\hline & Male & 126 & $34.3 \%$ & & Less than Rs.50,000 & 53 & $14.4 \%$ \\
\hline & Female & 241 & $65.7 \%$ & & Rs. $51,000-70,000$ & 72 & $20 \%$ \\
\hline & & & & & Rs. $71,000-99,000$ & 153 & $42 \%$ \\
\hline & & & & & Rs. $100,000-150,000$ & 89 & $24.3 \%$ \\
\hline & & & & & & & \\
\hline 2. & \multicolumn{2}{|c|}{ CONSUMERS AGE } & & 4. & \multicolumn{3}{|l|}{ EDUCATION } \\
\hline & $\begin{array}{l}\text { Younger } \\
\text { then } 18\end{array}$ & 57 & $15.5 \%$ & & Matric/ O- Level & 48 & $13 . \%$ \\
\hline & $18-30$ & 110 & $30.0 \%$ & & Intermediate/ A-Level & 54 & $15 \%$ \\
\hline & $30-45$ & 161 & $44 \%$ & & Graduation & 186 & $51 \%$ \\
\hline & $45+$ & 39 & $11 \%$ & & Master's Degree & 79 & $21 \%$ \\
\hline
\end{tabular}




\subsection{Descriptive Analysis of Research Variables}

The descriptive analysis of the implications of research variables shows that except personal selling and public relations all variables have a positive association. With the high mean value of 4.33 of DM consumers are highly influenced by direct marketing activities which have an impact on their purchase decisions. Similarly, technology with 3.73 and sales promotion with 3.76 mean value have high positive impacts towards consumers purchase decisions of products and services. Personal selling with mean of 2.7 elaborate that comparing to other variable s consumers are less influenced and have less impact of personal selling activities on CPD. As 2.99 mean value of CPD shows that IMC activities impact on consumers final purchase decision. The table given below shows the descriptive analysis of the research variables.

\begin{tabular}{|c|l|c|c|l|}
\hline \multicolumn{6}{|l|}{ Table 2: Descriptive Analysis of Variables Matrix } \\
\hline S.No & Constructs & N & Mean & Std. Deviation \\
\hline 1 & CONSUMER PURCHASE DECISIONS (CPD) & 367 & 2.9907 & .04209 \\
\hline 2 & ADVERTISING (AD) & 367 & 3.3569 & .89075 \\
\hline 3 & TECHNOLOGY (TCH) & 367 & 3.7302 & .32252 \\
\hline 4 & PERSONAL SELLING (PS) & 367 & 2.7248 & .59444 \\
\hline 5 & PUBLIC RELATION (PR) & 367 & 2.4909 & .08334 \\
\hline 6 & SALES PROMOTIONS (SP) & 367 & 3.7645 & .37334 \\
\hline 7 & DIRECT MARKING (DM) & 367 & 4.3308 & .37388 \\
\hline
\end{tabular}

\subsection{Consumers' Preferences Towards Purchase Decisions}

\begin{tabular}{|l|l|l|l|l|}
\hline \multicolumn{2}{|l|}{ Table 3: Tools Ranking Matrix } \\
\hline S.No & Tools & Frequency & Percent & Ranking \\
\hline $\mathbf{1}$ & Advertisement & 140 & $38 \%$ & 1 \\
\hline $\mathbf{2}$ & Sales Promotions & 62 & $17 \%$ & 3 \\
\hline $\mathbf{3}$ & Technology & 88 & $24 \%$ & 2 \\
\hline $\mathbf{4}$ & Personal Selling & 26 & $7.0 \%$ & 5 \\
\hline $\mathbf{5}$ & Direct Marketing & 51 & $14 \%$ & 4 \\
\hline & N & 367 & & \\
\hline
\end{tabular}

To find out the importance and consumers preferences of tools for their purchase decisions of products and services, the respondents ranked the given 5 tools of IMC. With the understanding of 1 being the most preferred and 5 being the least preferred, out of 367 respondents $38 \%$ ranked advertisement which influence them to make their purchase decisions, $24 \%$ ranked technology, $17 \%$ ranked sales promotions, $14 \%$ direct marketing and $7 \%$ ranked personal selling. This gives the clear picture of consumers' preferences that which tools are more important for the consumers for their purchase decisions. 


\subsection{Consumers' Preferred Sources for Awareness}

The respondents were asked about their preferences for the sources which helps in making them aware of the particular brand or product/services which further leads to their final purchase decisions. From the 367 respondents $92 \%$ preferred Television because it is commonly and conveniently in reach of consumers, $76 \%$ mentioned their preference in favor of outdoor advertisements/ sales promotions might be because consumers getting more benefits and rewards which delights them. Almost $67 \%$ respondents opted newspapers/ magazines, may be because newspapers and magazines consumptions comes in their daily routines $50 \%$ preferred internet / social media which make the respondents aware of brand/ products/services.

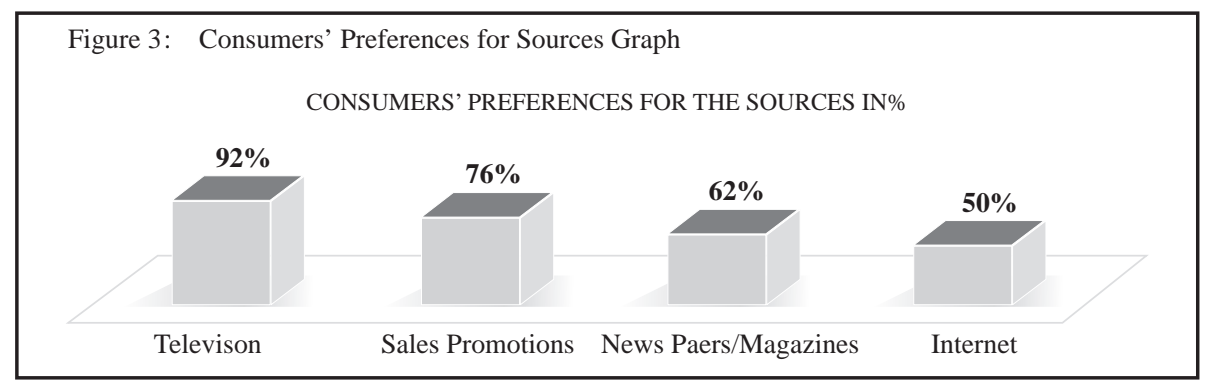

\subsection{Consumers" Preferences for Tools of IMC}

The respondents preferred advertising as the most important among all options of tools integrated marketing communications, it is because through advertising, marketers incorporated IMC effectively and advertisements play vital role in making consumers purchase decisions. Then respondents rated social media most obvious tool for engaging them with the brands which was $47 \%$ and sales promotion $43 \%$ because social media is becoming very popular where consumers interact and communicate and this trend is increasing day by day and sales promotions always attracted consumers as consumers get more benefits and rewards which delight them. Respondents preferred public relations with $32 \%$ indicating that consumers like to interact and associate with brands that they are using. Direct marketing is $28 \%$ which means direct marketing also engages consumers and helps them to make their purchase decisions. Personal selling was least considered by all.

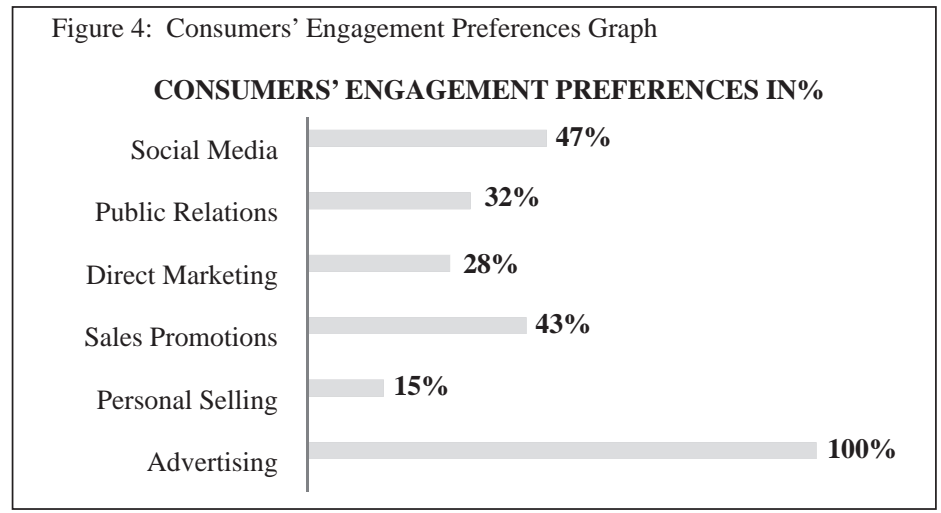

\begin{tabular}{l|llll}
\hline 32 & Jaunary - June 2013 & Volume 11 & Number 1 & JISR-MSSE
\end{tabular} 
4.6 Correlation Analysis

\begin{tabular}{|c|c|c|c|c|c|c|c|}
\hline & $\begin{array}{l}\text { Consumers } \\
\text { Purchase } \\
\text { Decisions }\end{array}$ & Advertising & Technology & $\begin{array}{l}\text { Personal } \\
\text { Selling }\end{array}$ & $\begin{array}{l}\text { Public } \\
\text { Relation }\end{array}$ & $\begin{array}{l}\text { Sales } \\
\text { Promotions }\end{array}$ & $\begin{array}{c}\text { Direct } \\
\text { Marketing }\end{array}$ \\
\hline $\begin{array}{l}\text { Consumer } \\
\text { Purchase } \\
\text { Decisions }\end{array}$ & 1 & & & & & & \\
\hline Advertising & $.144 * *$ & 1 & & & & & \\
\hline Technology & $.245^{* *}$ & $.488 * *$ & 1 & & & & \\
\hline $\begin{array}{l}\text { Personal } \\
\text { Selling }\end{array}$ & $-.184 * *$ & .082 & $.434 * *$ & 1 & & & \\
\hline $\begin{array}{l}\text { Public } \\
\text { Relations }\end{array}$ & $-.200 * *$ & $-.422 * *$ & $-.267 * *$ & .090 & 1 & & \\
\hline $\begin{array}{l}\text { Sales } \\
\text { Promotions }\end{array}$ & .094 & $.361 * *$ & $.351 * *$ & -.027 & $.310 * *$ & 1 & \\
\hline $\begin{array}{l}\text { Direct } \\
\text { Marketing }\end{array}$ & $.286 * *$ & $.617 * *$ & $.710 * *$ & $.124 *$ & $-.327 * *$ & $.262 * *$ & 1 \\
\hline
\end{tabular}

**. Correlation is significant at the 0.01 level (2-tailed).

*. Correlation is significant at the 0.05 level (2-tailed).

The above-mentioned table illustrates the correlation analysis of different variables of the research, analysis showing several significant correlations as IMC tools are playing vital role in making and influencing consumers purchase decisions. On the basis of respondents feedback, significant correlation among variable was found, with 0.144 shows a very strong positive relationship between consumers purchase decisions and advertising as increase in advertising has a positive impact on consumers so increase in creative effective advertising will also increase the influence on consumers purchase decisions,. Technology has a strong positive correlation with consumer purchase decisions and advertising the figure shows a strong relation which means technology has its impact on advertising and Consumer Purchase Decision as more advance technology will be used that will create synergy and will also influence the Consumer Purchase Decision. -0.188 show an inverse very strong negative correlation among personal selling as due to fast growing variety made the graph of personal selling down, so decrease/ increase in personal selling also impacting upon decrease/ increase consumer purchase decisions.

Personal selling has very weak correlation with advertising but has a very strong correlation 0.433 with technology as due to online selling able to again restart by using technology conveniently available for consumers. Public relations has very strong negative correlations which means if one will increase/decrease the other will inversely progress on opposite direction, Public Relations has strong inverse correlation with consumer purchase decision, advertising, technology, it would be the situation where physical services are used to more attract and target individuals using less technology but more customer focused and a very weak correlation with personal selling but it will not affect it prominently. As 0.027 shows inverse correlation between the sales promotions and personal selling, as one of them increase than other will decrease. Sales Promotions has strong positive correlation with advertising, 
technology and public relation as all the 3 are used in sales promotions to increase the selling. Direct marketing has very strong correlation with advertising .617, technology with 0.71 and sales promotions with .267 which means that direct marketing with effects of advertising and technology influence consumer purchase decision but it has a very strong inverse correlation with public relations which means that if public relations increased then direct marketing will decrease as now direct marketing is more towards on line interacting with consumers directly on one to one basis and public relations interacting indirectly through sponsorships, catalogues etc. In brief the correlation between variables shows that they are significantly correlated and IMC has its impacts on consumers purchase decisions and its activities that influence consumers in making their purchase decisions.

\subsection{Brand Manager Perspective}

\subsubsection{Interview Analysis with Assistant Brand Managers}

Interview with brand managers revealed information related to IMC implementations in Pakistani firms and the target market convictions. According to the brand manager's views, since past 7 years the market is able to see drastic changes, especially related to marketing tactics, in broad vision IMC practices have been started very late but rapidly the practices are changing as consumers have become more knowledgeable due to the availability of unlimited varieties in the market. To be in the competition the brand/firms has no option except lots of marketing activities which include best advertisements that attract consumers towards watching and recognizing the brand. To achieve a stable position in the market quality is one of the most important element but today, it is all about effectively conveying the brand's message to the target audiences using advance resources keeping the budget and time constraints as marketers priority. In such a brittle competition among all brands the goal is to seek and make the brand desirable in the mind of consumers.

The P\&G aggressively started implementing IMC practices which can be determinable by consumers, with effective planning, brain storming and evaluating the market in depth with all perspectives come in to the market. An ongoing aggressive competition in the industry, now several steps are being considered to incorporate various advance tools into integrated marketing communications according to the specific segments requirements to cater and building a modern and advance brand image in all marketing segments. Celebrity endorsement, advance techniques in electronic and print media all are the practices of IMC. The IMC is becoming an essential part of firm to be included in the successful brand race. Safeguard of $P \& G$ is currently focusing more commercials and print ads as these activities are very successful when considering pure Pakistani market perspectives. They have targeted children for safeguard and animated cartoon series in one of the most successful strategy which was out first step in incorporation of IMC in the marketing mix activities which was then followed by their competitors and now has become a trend for all businesses who's target market are children to appeal them through cartoon series or posters. The success factor of implementing the IMC activities depends on effective planning, involvement of all departments and lot of market research which initial starts from targeting and positioning of the brands. It is very important to be recognized by the stakeholders and recalling through commercials fully loaded with celebrities and glamorous looks to recall the brand and its image. Engro Foods Limited has already started to make a strong social plat form online under the umbrella of IMC working to start a separate department to interact with consumers through online and

\begin{tabular}{l|llll}
\hline 34 & Jaunary - June 2013 & Volume 11 & Number 1
\end{tabular}


other social channels. IMC practices started late because of the lack of researches and absences of updated information of international and globalized business market. Though all online and social media marketing is more cost effective, to be available for mass/ target audiences. Overall, incorporation of IMC practices by $\mathrm{P} \& \mathrm{G}$ are progressing with efficiency and to be more efficient it has already took the initiative of integrating the marketing activities which specifically include online media, sponsoring shows, donation collection programs, celebrities endorsement, sales promotions and focusing on social media and other platforms.

\subsection{Brand/Assistant Brand Manager Perspective}

To get the insight from professionals about the practices of IMC in Pakistan, only a few questions were asked during interview as due to the time constraints in depth interviews were not possible. So a questionnaire was developed consisted of open and closes ended questions but after receiving questionnaires open ended questions were eliminated as none of them provided their feedbacks on open ended questions. The researcher sent questionnaires to the brand manager / assistant brand manager of P\&G, Unilever and Engro Foods Limited . Total 15 questionnaires were returned out of which only 8 were accepted as they were completely filled.

\subsection{Questionnaire Analysis}

\subsubsection{Preferred Tools of Integrated Marketing Activities}

The managers were asked about the importance and their preferences of tools of marketing activities with respect to their brand to find out the importance of tools which are specifically implemented by the firms. The total 8 brand/assistant brand managers mentioned their preferences which are illustrated in the graph given below:

Figure 5: Marketing Activities Preferences \& Importance Graph

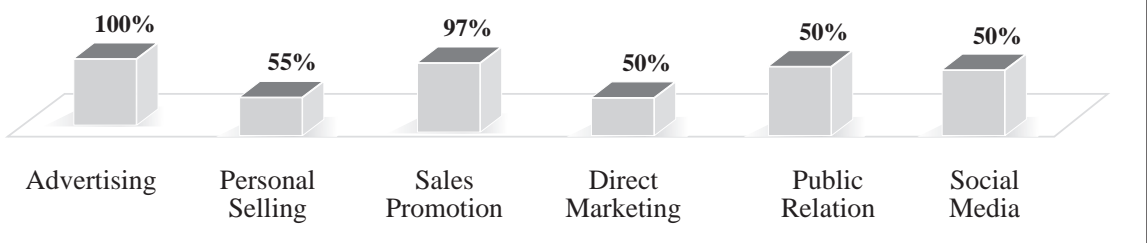

\subsubsection{Major Goals of Implementing IMC Activities}

The managers were asked to provide the information related to practicing their IMC activities in the firm, as they implement IMC activities according to their brand's visions and goals to efficiently achieve their desirable objectives. Customer relationship, loyalty were $100 \%$ chosen by them as they all are customers focused and to get the competitive edge they want to be more customer focused. As they are already established brands so they are least focused on brand positioning.

\begin{tabular}{lll|l}
\hline JISR-MSSE & Volume 11 & Number 1 & Jaunary - June 2013
\end{tabular}




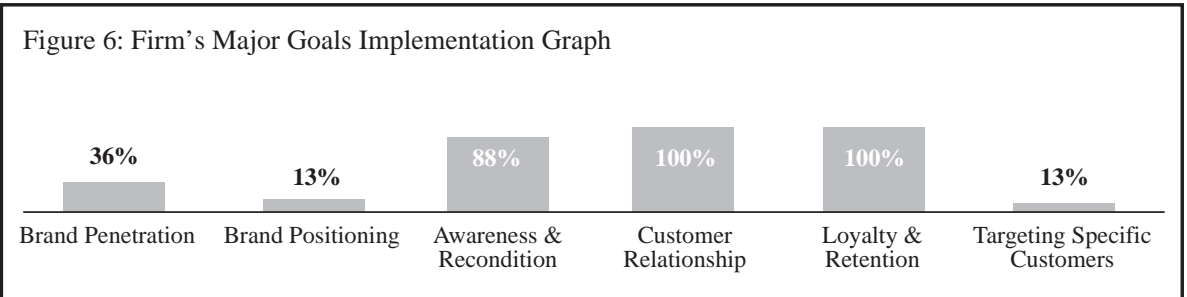

According to brand managers opinions advertising and sales promotions are the most important tools with consumers' perspective so it is obvious that they are more focused towards these tools which are more conveniently reachable to the masses. Personal selling is least preferred probably because FMCG brands are focus to target the mass or due to budget and time constraints.

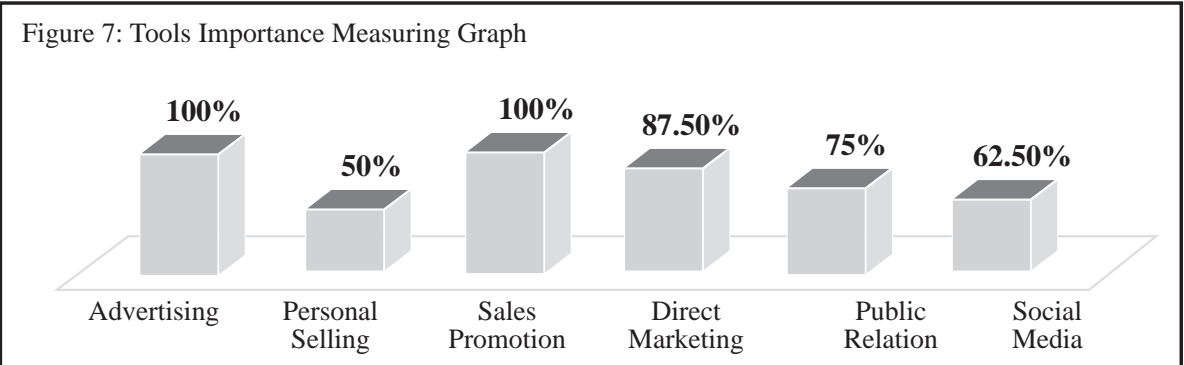

\section{Conclusion}

The major objective of this study was to find out the impact of IMC on consumers purchase decisions, mainly to the understanding of consumers. This research confirms the importance of IMC activities and concludes that IMC is the best to target the consumers, because the consumers are strongly influenced by IMC implementations. The research also confirms the past research literatures are valid and reliable after data analysis of consumers' and brand managers' feed backs. Concluding the consumers feedback it is obvious that they want firm to incorporate IMC activities as they are well informed and able to purchase from the variety of brands available, so which brand reach them more effectively will influence them more. Advertising and sales promotions were the most important tools of IMC practices for consumers which means that they are more in touch with these tools as compare to other.

Technology is another important aspect for them as consumers are getting more involved in to social media, internet and online activities, they want to feel important so they also preferred direct marketing but that depends on type of brand they are purchasing. Consumers' feedback and preferences can be used in planning and implementing IMC activities more efficiently. This study highlights that traditional marketing would not be useful anymore, as consumers are more demanding and well informed with variety of brands available in the market, though they have limited purchasing power. The outcomes and relevant directions and dimensions

\begin{tabular}{l|llll}
\hline 36 & Jaunary - June 2013 & Volume 11 & Number 1 & JISR-MSSE
\end{tabular}


can be utilized by marketers, as social media being the main tool can be used by the marketers due to social media firms are able to directly communicate with target market and able to get their feed backs which can bring more effective implementation of the IMC activities. The feedback of brand managers were restricted and limited one of the reasons could be they are not aggressively implementing IMC activities as compare to international practices and more focused on traditional practices and other reason is that the firms are outsourcing for implementing the advance marketing activities on high budgets. The brand managers are very well informed about the tools and elements in the market but how much they are able to utilize and implement in their practices is not obvious.

On the basis of feedback and analysis this study concludes that IMC should be practiced from all perspectives of marketing tools. Focusing on few traditional practices is not appropriate strategy. This study emphasized that IMC practices should be research based with market and consumers perspectives, for effective IMC practices all department should work together. Moreover, the research analysis also enforces on the exposure to the advance technology which needs to be considered at all level. The firm should make an IMC model considering the firm's structure and the environment in which they are competing. Instead of outsourcing to different agencies for each brand it is better to make a separate team or hire one specific specialized agency that will be in continuous interaction with the firm and its brand with better understanding clear picture of firms' goals.

\section{Implications}

IMC is a non-stop process which transmits a chain of messages to the stakeholders in quest of the organization's objectives, recognition, persuasion, recall, communication and building image to depict product and service (Fill, 2001). The modern practices of IMC are worth studying. The IMC practice is the necessity in today's business practices which highlight the importance of strategic integrating marketing communications tools. Firms need to analyze the changing preferences of consumers and this study provides the consumers' which based on variation effectively interact and communicate with the stake holders. The main purpose of this research focuses on the IMC implementations in Pakistan which influences the buyers purchase decision but need to be implemented with the consistency and according to the desire of the target market. The challenge for the local firms is to cope up with marketing communication practices with the fusion of available resources and various communication channels and building an understanding of consumers' preferences. This study will help the firms to recognize the adaptation in their marketing practices according to the changing environment and changing consumers' buying trends and highlight the important tools which are mostly preferred by the consumers in the context of catering target market by implementing IMC activities. 


\section{References}

Albesa, J. G. (2007). Interaction channel choice in a multichannel environment, an empirical study". International Journal of Bank Marketing, 25 (7), 490-506.

Ambler, T, Bhattacharya, C. B, Julie E., Kevin L. K., Katherine N. L., \& Mittal., V. (2002). Relating Brand and Customer Perspectives on Marketing Management, Journal of Service Research, 5, 13-25.

Alvesson, M., \& Sköldeberg, K. (2009). Reflective Methodology: New Vistas for Qualitative Research. 2nd ed. Thousand Oaks: Sage Publications, Inc.

Baines, P., Fill, C., \& Page, K. (2008). Marketing: Case insight. Oxford: Oxford University Press.

Baker, S., \& Mitchell, H. (2000). Integrated marketing communication: Implications for managers. European Society for Opinion and Marketing Research, 239-241.

Belch, G. E., \& Belch, M. A., (2004). Advertising and promotion: an Integrated Marketing Communications perspective. 6th edition. New York: Tata McGraw-Hill.

Berthon, P.R., Pitt, L. F., \& Campbell, C. (2008). Ad lib: When customers create the ad. California Management Review, 50(4), 6-30.

Bezjian,.A. A., Calder, B., \& Lacobucci, D. (1998). New media interactive advertising vs. traditional advertising. Journal of Advertising Research, 38(4), 23-32.

Blood, R. (2002). The web log handbook: Practical advice on creating and maintaining your blog. Cambridge.

Bryman, A., \& Bell, E. (2007). Business research methods (2nd ed.). New York: Oxford University Press.

Carlson, L., Stephen J. G., \& Michael J. D. (2003). Services Advertising and Integrated Marketing Communications: An Empirical Examination, Journal of Current Issues and Research in Advertising, 25, 68-82.

Creswell, J. W. (2003). Research Design-Qualitative, Quantitative, and Mixed Methods Approaches. Thousand Oaks: Sage.

Devers, K. J., \& Frankel, R. M. (2000). Study design in qualitative research: sampling and data collection strategies. Education for Health, 13, 263-271.

Duncan, T., \& Caywood, C., (Eds.) (1996). The Concept, Process, And Evolution of Integrated Marketing Communication. Mahwah, N. J., Lawrence Erlbaum Associates.

Duncan, T., \& Moriarty, S. E. (1998). A Communication-based marketing model for managing customer relationships, Journal of Marketing, 62, 1-14.

\begin{tabular}{l|llll}
\hline 38 & Jaunary - June 2013 & Volume 11 & Number 1
\end{tabular}


Duncan, T. (2002). IMC: Using Advertising \& Promotion to Build Brands. New York: McGrawHill.

Durkin, M., \& Lawlor, M. A. (2001). The implications of the internet on the advertising agency-client relationship. The Services Industries Journal, 21(2), 90-175.

Duncan, T. R. \& Mulhern, F. (2004). A white paper on the status, scope and future of IMC. IMC Symposium co-sponsored by IMC programs at Northwestern University and University of Denver.

Eagle, L., \& Kitchen, P. J. (2000), IMC, brand communications, and corporate cultures client/advertising agency co-ordination and cohesion. European Journal of Marketing, $37(1), 667-86$.

Fill, C. (2002), Marketing Communications: Contexts, Strategies and Applications (3rd ed.). Harlow: Pearson Education.

Kallmeyer, J., \& Abratt, R. (2001), Perceptions of IMC and organizational change among agencies in South Africa, International Journal of Advertising, 20(3).

Kitchen, P. J. \& Schultz., D. E. (2000). A response to theoretical concept or management fashion? Journal of Advertising Research, 40(5), 17-21.

Kitchen, P. J., Joanne B., Li.,T. \& Jones., G., S. (2004). The Emergence of IMC: A Theoretical Perspective, Journal of Advertising Research, 44 (1), 19-30.

Kitchen, P. J. (2005). New Paradigm-IMC under fire. Competitiveness Review, 15(1), 72 80.

Knox, S., \& Maklan, S. (2004). Corporate Social Responsibility: Moving Beyond Investment Towards Measuring Outcomes, European Management Journal, 22(5), 508-516.

Kotler, P., \& Armstrong, G. (2008). Principles of Marketing (12th ed.). Mishawaka, USA: Prentice Hall.

Levinson, J. C. (2001). Integrated marketing, executive excellence. Provo, 18(11), 9-10.

Logsdon, Jeanne M., \& Wood, Donna J. (2002). Business citizenship: from domestic to global level of analysis. Business Ethics Quarterly, 12(2), 155-187.

Low, G. (2000), Correlates of integrated marketing communications, Journal of Advertising Research, 40(2).

Ragins, E. J., \& Alan J. G. (2003). Customer Relationship Management and E-Business: More Than a Software Solution. Review of Business, 24(1), 25. 
Raman, R., \& Annamalai,V. (2010). Web as New Advertising Media among the Net Generation: A Study on University Students in Malaysia. Journal of Business \& Policy Research, 5(1),79-86.

Reid, M. (2003). IMC-Performance Relationship: Further Insight and Evidence from the Australian Marketplace. International Journal of Advertising, 22 (2), 227-248.

Reid, M., Sandra, L., \& Mavondo, F. (2005). The relationship between integrated marketing communication, market orientation, and brand orientation. Journal of Advertising, 34(4), 11-23.

Rust, R. T., Tim, A., Gregory S. C., Kumar,V., \& Rajendra K. S. (2004). Measuring Marketing Productivity: Current Knowledge and Future Directions, Journal of Marketing, 68, 76-89.

Schultz, D., E., Bill., C., \& Scott, B. (2000). Implementing the 'Connect the Dots' Approach to Marketing Communications. International Journal of Advertising, 23(4), 455-477.

Shao, G. (2008). Understanding the appeal of user-generated media: a uses and gratification perspective. Internet Research, 19,7-25.

Smith, P. R. (2002). Marketing Communications: An Integrated Approach (3rd ed.). London: Kogan Page.

Smith, P. R., \& Taylor, J. (2004). Marketing Communications: An Integrated Approach (4th ed.). Malta: Gutenberg Press.

Tellis, G. J. (2006). Effective advertising: Understanding when, how and why advertising works. Thousand Oaks, CA: Sage Publications.

Waheed-u-zzaman, A., \& Dube, L. F. (2004). Trends and development in standardization adaptation research. Journal of Global Marketing, 17(4), 23-52.

Weitzman, E. A. (1999). Analyzing qualitative data with computer software. Health Services Research, 34, 1241-1263. 